\title{
Does Knowledge Stickiness Affect a Firm's Innovation Capability? Empirical Evidence From Indonesian Furniture SMEs ${ }^{1}$
}

\author{
Nurul Indarti \\ Faculty of Economics and Business, Universitas Gadjah Mada, Yogyakarta, Indonesia
}

\begin{abstract}
This study aims to examine the relationship between knowledge stickiness and a firm's innovation capability in the context of developing countries, i.e., Indonesia. The main research question addressed by this study is: does knowledge stickiness affect a firm's innovation capability? Using data from 100 small- and medium-sized furniture enterprises (SMEs), the study finds that product innovations are predominant over process and organizational ones. However, incremental innovations are often more preferred than radical ones. This study also finds that the firms absorb knowledge from various sources to undertake innovations. Buyers, Internet, and suppliers are the significant sources, for sensory, coded, and theoretical knowledge. Buyers are also the main source of a great extent of various knowledge domains related to product, process, and organizational innovations.

In general, the furniture firms do not pay considerable attention to planning stages when introducing innovations, as indicated by the fact that not all innovations are preceded by initiatives, except for really new processes and organizational innovations whose impact on the firms' revenue is less visible. Out of four dimensions of knowledge stickiness used in this study, three of them (i.e., knowledge interconnectedness, sensory knowledge, and coded knowledge) are proven to have significant impact on a firm's innovation capability. We find, knowledge interconnectedness and coded knowledge have a positive impact, while sensory knowledge influences a firm's innovation capability in a negative direction. All in all, this study provides empirical evidence that knowledge stickiness has a significant impact on a firm's innovation capability (explains $36 \%$ of total variance).
\end{abstract}

Abstrak: Penelitian ini bertujuan untuk menguji hubungan antara kelengketan pengetahuan dan kemampuan inovasi perusahaan dalam konteks negara berkembang (i.e. Indonesia). Pertanyaan utama yang dijawab dalam penelitian ini adalah apakah kelengketan pengetahuan mempengaruhi kemampuan inovasi suatu perusahaan? Berdasarkan data 100 perusahaan mebel berskala kecil dan menengah (UKM) di Indonesia, penelitian ini menunjukkan bahwa inovasi produk banyak dilakukan oleh UKM di Indonesia dibandingkan inovasi proses dan organisasional. Sementara itu, dari tingkat kebaruan, inovasi incremental jauh lebih sering dilakukan daripada inovasi radikal. Penelitian ini juga menemukan bahwa perusahaan menyerap berbagai pengetahuan untuk melakukan inovasi. Pembeli, Internet, dan pemasok merupakan sumber-

\footnotetext{
${ }^{1}$ Empirical data were based on the work of Indarti (2010)
} 
sumber utama bagi pengetahuan sensori, terkode, dan teoretikal. Disamping itu, pembeli adalah sumber utama yang menyediakan berbagai pengetahuan yang relevan dalam inovasi produk, proses, dan organisasional.

Temuan lain, secara umum, perusahaan mebel tidak memberikan cukup perhatian pada tahap perencanaan ketika melakukan inovasi. Kenyataannya, tidak banyak inovasi yang dihasilkan diawali dengan tahapan inisiasi, kecuali untuk inovasi proses dan organisasional yang memberikan impak tidak terlalu besar bagi pendapatan perusahaan. Dari empat dimensi kelengkatan pengetahuan yang diteliti, tiga di antaranya (i.e. ketertautan pengetahuan (knowledge inteconnectedness), pengetahuan sensori dan pengetahuan terkode) yang terbukti mempengaruhi kemampuan inovasi perusahaan. Lebih rinci, ketertautan pengetahuan dan pengetahuan terkode memberikan pengaruh positif sedangkan pengetahuan sensori berpengaruh negatif terhadap kemampuan inovasi perusahaan. Penelitian ini juga memberikan bukti empiris bahwa secara keseluruhan kelengketan pengetahuan mempunyai pengaruh signifikan pada kemampuan inovasi perusahaan (menjelaskan sebesar 36\% dari total varians).

Keywords: furniture SMEs; Indonesia; innovation capabilities; knowledge stickiness 


\section{Introduction}

In a stiffer business competition environment, firms need to adapt and improve their products/services on a continuous basis in order to survive. In doing so, businesses need to acquire and utilize their existing/new resources to be able to produce innovative outputs. The resource-dependency theory (i.e., Pfeffer and Salancik 1978; Ulrich and Barney 1984) views an organization as an open system which cannot solely rely on its own resources (knowledge) for its survival, but which must also mobilize means from the external business environment. Most firms actively absorb and adopt resources (knowledge) from other companies, whether they do it on purpose or by accident.

(New) knowledge has several characteristics. These characteristics may influence the capability to absorb and utilize this knowledge in its innovation policies. The degree to which it is easy or difficult for an organization to absorb information from the environment, is called the stickiness of external knowledge. We believe that the stickiness of external knowledge in terms of its content (i.e. product, process, organizational) and its types affect a firm's innovation capability. In this study, stickiness is viewed from the perspective of the receiver.

The capability to deal with (external) knowledge and to utilize it, is called a firm's absorptive capacity (ACAP) (Cohen and Levinthal 1990). Examining ACAP i.e., the firm's capability to recognize and obtain external knowledge as a useful resource in the process of innovation, is a highly relevant task in gaining insight into the dynamics of a firm's innovativeness. Many authors argue that ACAP promotes the speed, frequency, and magnitude of innovation(s), which in turn generates new knowledge that again becomes part of the ACAP of the organization (Kim and Kogut 1996; Helfat 1997; Van den Bosch et al. 1999). From this perspective, innovation can be considered as the output of a firm's ACAP (Lane et al. 2002).

To our knowledge, most studies of these issues were undertaken in the context of developed countries. This study aims to examine the relationship between knowledge stickiness and a firm's innovation capability in the context of developing countries, i.e., Indonesia. The main research question addressed by this study is: does knowledge stickiness affect a firm's innovation capability?

The structure of the paper is as follows. Section 2 discusses theory and hypotheses. Section 3 explains the research methodology. Findings and discussion are presented in Section 4. Finally, section 5 presents concluding remarks.

\section{Theoretical Framework and Hypotheses}

\section{Innovation Capability as an Output of a Firm's $A C A P$}

The original concept of ACAP was introduced by Cohen and Levinthal (1990). Since then it has been intensively studied and adapted by a fair number of scholars. Zahra and George (2002) redefined ACAP as a set of organizational routines and processes, by which firms acquire, assimilate, transform, and exploit knowledge. The relevance of this construct is reflected by the importance of external knowledge in the stimulation of a firm's innovation activities. Since ACAP is closely related to external knowledge (Cohen 
and Levinthal 1990), this study will particularly pay attention to external determinants i.e., the characteristics of external knowledge.

Innovation is the application of new knowledge by which a firm is better able to meet the needs of its customers. It is realized by the introduction of new/improved products or by providing new/improved) services to customers. In this respect, a better use of existing knowledge as well as a more effective acquisition and assimilation of (new) knowledge collected from external sources, are very important for a firm's growth. Since knowledge is the key to innovation, it is of great importance for an organization to be able to absorb, assimilate, and utilize knowledge from all available sources (Van den Bosch et al. 1999).

Innovations can in this context be seen as a multidimensional concept (Neely et al. 2001). Schumpeter (1934) defines innovation as "1) the introduction of a new good ...; 2) the introduction of a new production method $\ldots$; 3) the opening of a new market ...4) the opening of a new source of supply ... 5) the carrying out of the new organization of any industry ..." (p. 66). Shortly, innovation can be considered as the introduction of something new into an organization (Jorna 2006).

In addition, business and innovation literature offers various classifications of innovations that have been developed and applied (e.g., Schumpeter 1934; Johannessen et al. 2001; Avermaete et al. 2003). Some authors (e.g., Avermaete et al. 2003; Johannessen et al. 2001) discuss innovation from the perspective of output (e.g. product, process, organizational), while others (e.g., Damanpour 1996; Jansen et al. 2006; Abernathy and Clark 1985) describe the concept in terms of the degree of change (i.e., radical and incremental). Yet another perspective used in capturing the dynamic process of innovation is that of the various stages of innovation (i.e., initiative and actual innovation).

\section{Knowledge Content and Types}

Knowledge is considered as the major form of input for economic processes and a crucial precondition for the possibility of firms, communities, and individuals to participate successfully in the global economy (Reich 1991; Hollifield and Donnermeyer 2003). Both the resource-based and the knowledge-based theory stress the existence and importance of knowledge as a strategic resource in maintaining a firm's competitiveness (e.g., Penrose 1959; Barney 1991; Nonaka 1994; Kogut and Zander 1992; Grant 1996). Especially new knowledge stimulates business opportunities, serving as valuable input and output in economic activities, even in poor countries (Melody 1985). Several studies indicate a significant effect of (new) knowledge on firms' survival and innovativeness (Rothwell 1991; Kristiansen et al. 2005).

Knowledge can be classified on the basis of its content. Knowledge content represents what the knowledge is about; it can consist of domains, fields, and disciplines (Jorna 2006). The field of management is an example of a knowledge domain. Within this field there are several specializations, such as marketing, operations, human resource, and finance. Additionally, there may be more narrow segments such as inventory control, scheduling, and quality control within operations management. In this study, we used a categorization of the knowledge domains by Kristiansen et al. (2005) and a simplification of Porter's value-chain model to adjust it to the context of SMEs, which in our case resulted into three knowledge domains: products, process, and organizational aspects. 
In the knowledge management literature, types of knowledge have been classified in various ways. For instance, Polanyi (1962) has 'traditionally' classified knowledge into tacit and explicit knowledge, while Boisot (1995) has grouped it into coded and uncoded knowledge. The current study focuses on knowledge at the individual and organizational levels in the context of SMEs. Knowledge is embedded in the individual's mind (e.g. Nonaka et al. 2000). Since a firm may be considered as a collection of people (Davenport and Prusak 1998) or as a collection of humans as information-processing systems (Jorna 2006), knowledge of each individual in an organization can be regarded as organizational knowledge (Nelson and Winter 1982). This line of reasoning implies a cognitive perspective on knowledge (Nooteboom 1996; Jorna 2006). Therefore, we have taken the cognitive perspective as our point of departure, using the types of knowledge as proposed by Cijsouw and Jorna (2003), namely sensory, coded, and theoretical knowledge.

\section{Sensory knowledge}

Tacit knowledge has originally been characterized by Polanyi (1966) as personal, context-specific, and therefore hard to formalize and communicate. This type refers to the knowledge which is embedded in the mind of the individual (Nonaka and Kanno 1998) and which cannot be separated from this person. Since this knowledge is based on the background and experience of its carrier, it is highly personal (Roberts 2000). Nelson and Winter (1982) argue that a large part of human knowledge is context-bound, highly specific, and tacit in nature, and that there are limits to the degree to which it can be articulated and transferred. From another perspective, Cijsouw and Jorna (2003) propose to divide tacit knowledge into sensory and theoretical knowledge. Sensory or behavioral knowledge is knowledge of situations and events expressed in the form of behavior, procedures, and habits, which can be observed and imitated. Sensory knowledge is very dependent on its context, it diffuses slowly, and it is time-bound. As a characteristic, it cannot be expressed in words, only in behavior. Sensory knowledge can be categorized in terms of level of detail, depending on the degree of detail acknowledged by the recipient, into rough sensory knowledge and detailed sensory knowledge (Cijsouw and Jorna 2003; Jorna 2006). From the perspective of the recipient, rough sensory knowledge is less accessible, and hence stickier.

\section{Coded knowledge}

Knowledge can also be expressed in various kinds of codes. Coded knowledge includes the use of signs and symbols referring to objects or experiences (Jorna 2006). By using coded knowledge it is possible to communicate and exchange information without the actual presence of the object to which this knowledge refers or even without the presence of the communicating actor him/herself (Jorna 2006). For instance, we can talk about tables or computers without their actual presence. The code itself represents the knowledge. Coded knowledge is linked to the context of the code by means of language or a collection of pictograms (Jorna 2006). Therefore, coded knowledge can be transferred quite easily within a community if its members know the codes (Jorna 2006). Coded knowledge may be represented by various kinds of symbols. These symbols may range from weakly- to strongly-coded, i.e. from icons or pictures, diagrams, schemes, to language/texts and formulae. Each representation has its own degree of ambiguity. A code 
is 'better' if it reduces ambiguity (Cijsouw and Jorna 2003: p. 220). From the perspective of the recipient, knowledge with higher codedness (strongly coded) is more accessible, and hence less sticky.

\section{Theoretical knowledge}

Theoretical knowledge refers to the understanding of a structure or pattern of a concept (object, or event) (Cijsouw and Jorna 2003). Understanding a concept implies that it can be explained and reasoned about; one is able to use its terminology correctly and to indicate its relations with other concepts (Cijsouw and Jorna 2003). People use theoretical knowledge when they answer whyquestions. On the basis of this knowledge people are able to identify structural (Cijsouw and Jorna 2003) as well as causal relations (i.e. if-then-relations). Theoretical knowledge is generally found among the well-educated owners/managers of firms. The more complicated the why-connection or the causal relations, the more abstract the knowledge is. It is therefore stickier.

\section{Knowledge Sources}

The stakeholder theory argues that there are various parties involved or that affect or can be affected by the actions of the business as a whole (Philips and Freeman 2003). The parties can be classified into primary and secondary stakeholders. The primary stakeholders are those that engage in economic transactions with the business such as employees, customers and suppliers. The secondary stakeholders are those who - although they do not engage in direct economic exchange with the business - are affected by or can affect its actions, such as government offices, business associations, communities, universities and the media. Sometimes even competitors are counted as stakeholders.

Based on the concept of stakeholders, the nature of interaction and the previous studies (e.g. Smeltzer et al. 1988; van Geenhuizen and Indarti 2008), in this study, we classify 13 knowledge sources: (1) buyers, (2) suppliers, (3) competitors, (4) consultants, (5) government offices, (6) industry associations, (7) religious affiliations, (8) research institutions/universities, (9) exhibitions, (10) magazines/newspapers, (11) radio, (12) television, and (13) Internet.

\section{Knowledge Stickiness}

The concept of stickiness was initially used in macroeconomics as 'sticky prices' to express prices that were slow to adjust. From the neoclassical point of view, stickiness of knowledge is viewed in terms of money or cost (Arrow 1962; Von Hippel 1994). Von Hippel (1994) discusses the well-known path of resistance between a firm's research labs and its engineering department. In the strategy literature, sticky has been used as a synonym for inert (Porter 1994) or difficult to imitate (Foss et al. 1995). Szulanski (1996) uses the term of 'internal' stickiness to indicate a firm's barriers to transferring knowledge (i.e., best practice) from one part of the organization to the other. In general, discussions about stickiness have primarily focused on the movement or absorption of knowledge inside a firm (Brown and Duguid 2001). In the context of this study, the concept of knowledge stickiness (Szulanski 1996 2000) is redefined, to refer to the stickiness of knowledge exchange across organizations or between an organization and its (external) business environment.

The stickiness is a complex concept, which can be approached from different 
points of view. In this study, stickiness refers to the degree of accessibility. Knowledge is considered as sticky if its accessibility is low. Accessibility is a multidimensional concept (Culnan 1985). According to the Cambridge Advanced Learner's Dictionary, accessibility is the degree to which a piece of knowledge is easy to understand or reach. Culnan (1985) provides a definition, which covers the physical access to the source, the interface to the source, and the ability to physically retrieve potentially relevant knowledge (Culnan 1985).

These definitions imply at least three kinds of accessibility, namely cognitive, physical, and financial. A piece of knowledge may be considered as sticky if it is difficult to understand it cognitively because, for instance, it is presented in complex formula or in a foreign language, or located at a remote physical distance. A piece of knowledge that is costly to access may also be considered as sticky. The current study specifically emphasizes the cognitive accessibility of external knowledge. It does not deal with its financial accessibility.

Knowledge stickiness in this study is approached from types of knowledge, i.e., (a) sensory, (b) coded, and (c) theoretical knowledge. In addition, knowledge interconnectedness is also used. The interconnectedness of knowledge refers to the degree to which knowledge covers various domains (Simon 1976; Jorna 2006; Van der Spek and Spijkervet 1997). When a piece of absorbed knowledge consists of several interconnected domains, it provides a fuller picture of specific information, which in turn makes the knowledge as a whole easier to absorb and understand. From the perspective of the recipient, for example, the knowledge obtained from the buyers has a higher level of inter- connectedness than that provided by the governmental office, because it contains more knowledge domains. Therefore, the knowledge provided by the buyers has a higher degree of accessibility. In other words, the more interconnected domains of knowledge are available, the higher the degree of accessibility. The higher the degree of accessibility, the lower the stickiness, and consequently, the higher a firm's innovation capability.

Based on the above theoretical framework and arguments, the following hypotheses are formulated:

$H_{1}$ : The more sensory the external knowledge, the lower a firm's innovation capability

$H_{2}$ : The higher the codedness of the external knowledge, the higher a firm's innovation capability

$H_{3}$ : The more theoretical the external knowledge, the lower a firm's innovation capability

$H_{4}$ : The higher the interconnectedness of the external knowledge, the higher a firm's innovation capability

\section{Research Methods}

\section{Research Instrument}

The questionnaire we developed consists of three parts. The first part consists of questions on demographical characteristics of the owners and the firms. The last two parts consist of items to measure stickiness of knowledge and innovation capability.

Innovation capability is measured using 12 items referring to initiatives and to innovations concerning both modifications and new innovations (i.e., product, process, and organizational innovation), by using a 5 -point Likert scale ( $1=$ very seldom; $5=$ very often) (see Johannessen et al. 2001; van Geenhuizen and Indarti 2005; Jansen et al. 2006). 
Knowledge stickiness is operationalized in four separate variables: sensory knowledge (13 items), coded knowledge (13 items), theoretical knowledge (13 items), and knowledge interconnectedness (39 items). Items to measure the first three variables were adopted from Cijsouw and Jorna (2003), while those to measure knowledge interconnectedness were adopted from Porter (1985); Kristiansen et al. (2003) and Jorna (2006). Sensory knowledge is measured by asking question is how easily can you show or demonstrate within your firm the knowledge you received from (a specific knowledge source)? Scores of coded knowledge is obtained by asking a question: how easily can you write down in terms of manuals, instruction guides and procedures, knowledge from (a specific knowledge source)? The question to measure theoretical knowledge is: within your firm, how easily can you explain the knowledge -in terms of why and how- obtained from (a specific knowledge source)? All these questions are applied to 13 knowledge sources mentioned above, and are measured in a 5point Likert scale $(1=$ very easy; $5=$ very difficult). Lastly, scores for knowledge interconnectedness are obtained by asking a question: based on your experience within the past 2-years, please indicate the specific knowledge content (i.e. a) products; b) process c) organizational you obtained from (a specific knowledge source) and indicate the depth of the knowledge per domain. These questions are also applied into 13 knowledge sources, and are measured in a 5-point Likert scale $(1=$ very little; $5=$ very difficult). The score is zero if the respondent considers that the specific knowledge source does not provide any knowledge at all.

\section{Data Collection Procedure}

The respondents of this study are the managers/the owner of the Indonesian furniture SMEs. The province of Yogyakarta with high density of furniture SMEs is selected to be a research site. Spatial analysis from a previous research (Kuncoro 2000) found that Yogyakarta is one of the cities in the island of Java where many SMEs are clustered. Besides a database from the Indonesian Furniture Industry and Handicraft Association, the sampling will also be based on visibility of the manufacturers and researchers' knowledge about existence and development of the furniture industries in the region.

Data were collected in the period October 2007-March 2008, using personal interviews (about 45-60 minutes) and the "drop and collect" procedure. Out of 322 furniture firms on the list, 168 were not eligible as respondents since they were in operation for a period shorter than two years. The remaining 154 firms were contacted, and only 100 of them were willing to partake in the study, making the response rate of 64.9 percent and these entire returned questionnaires were valid for next analysis.

\section{Data Analysis Methods}

Obtained data from the filled questionnaire is tabulated. Reverse scoring is deployed for unfavorable items. Because all questions in the questionnaire are closed-ended ones, a statistical software package, SPPS, is appropriate to be used in data analysis. In addition to descriptive analysis (i.e. central tendency), to examine relationships between variables, regression analysis is deployed. 


\section{Findings and Discussion}

\section{Demographic Information}

Most respondents $(86.0 \%)$ are male and are on average 40 years old. The majority of the respondents have a university background $(63.0 \%)$ and have worked at various working sectors $(73.0 \%)$. Most furniture firms in the sample are independent $(98.0 \%)$ and are located in a rural situation $(37.0 \%$ in sub-urban and $36.0 \%$ in village). The initiation to start a furniture business is mostly $(82.0 \%)$ from the owner. On average, the number of employees is 21 and the duration of opera- tions is eleven years. Since its establishment, many $(37.0 \%)$ respondents argue that their firms start growing after 2 years. Domestic markets account for 51.56 percent of revenue of the firms while export markets make up until 48.44 percent of total revenue. The export destinations are around the world such as the Netherlands, Germany, Spain, France, England, Australia, Japan, South Korea, China, and Malaysia. A majority $(94.0 \%)$ of the firms' monthly revenue is less than IDR 100 million (USD 10,034) ${ }^{2}$ and only 6.0 percent have more than IDR 150 million (USD 14,940). Additionally, personal savings are the most dominant $(70.30 \%)$ sources of capital.

Table 1: Knowledge Domains and Interconnectedness

\begin{tabular}{lcccc}
\hline \multirow{2}{*}{\multicolumn{1}{c}{ Source }} & \multicolumn{3}{c}{ Knowledge on } & \\
\cline { 2 - 4 } & Product & Process & $\begin{array}{c}\text { Organiza- } \\
\text { tional }\end{array}$ & $\begin{array}{c}\text { Inter- } \\
\text { connectedness }\end{array}$ \\
\hline Buyers & 3.37 & 1.16 & 1.30 & 1.70 \\
Suppliers & 0.96 & 1.40 & 0.54 & 0.78 \\
Competitors & 1.59 & 1.08 & 0.97 & 1.13 \\
Consultants & 0.34 & 0.27 & 0.43 & 0.28 \\
Government offices & 0.32 & 0.29 & 0.56 & 0.32 \\
Industry associations & 0.93 & 0.77 & 1.01 & 0.84 \\
Religious affiliations & 0.23 & 0.19 & 0.28 & 0.20 \\
Research institutions/universities & 0.26 & 0.19 & 0.19 & 0.19 \\
Exhibitions & 2.31 & 0.99 & 1.33 & 1.43 \\
Magazines/newspapers & 2.25 & 1.17 & 1.21 & 1.42 \\
Television & 1.07 & 0.59 & 0.49 & 0.61 \\
Radio & 0.09 & 0.11 & 0.12 & 0.09 \\
Internet & 2.11 & 1.10 & 1.31 & 1.42 \\
\hline
\end{tabular}

Note: Measured using a 5 -point Likert scale $(0=$ not at all, $1=$ very little, $5=$ very much).

\footnotetext{
${ }^{2}$ www.xe.com, accessed on May 21st 2011
} 


\section{Characteristics of External Knowledge}

\section{Domains and interconnectedness of external knowledge}

As shown in Table 1 , buyers (mean=3.37), exhibition (mean=2.31), magazines $/$ newspapers (mean $=2.25$ ) are the most dominant knowledge sources that provide the knowledge content on product. Examples of knowledge on product domain are new product design and modification design, and new chair/table/bed. As regards knowledge content on process, suppliers (mean $=1.40)$ are the most important source. Process domain varies from knowledge about raw material (e.g. types of wood, quality and the use of materials), production process (e.g. delivery procedures, wood installment techniques), equipment/technology (e.g. connection techniques, type of tools used). Knowledge on organizational innovation mostly is obtained from exhibitions (mean $=1.33$ ), Internet $($ mean $=1.31)$, and buyers (mean $=1.30)$.

Moreover, knowledge provided by the buyers is the most interconnected, followed by exhibitions and the Internet (see Table 1). The radio, on the other hand, scores the lowest on interconnectedness, followed by religious affiliations. In summary, knowledge provided by buyers and the Internet is the least sticky, whereas that obtained from the radio and religious affiliations is the stickiest. It appears that with respect to acquiring knowledge, small firms are more inclined to approach and interact with external parties/ sources with which they are acquainted (Fann and Smeltzer 1989).

Table 2. Sensory, Coded, and Theoretical Knowledge

\begin{tabular}{lcccccc}
\hline \multirow{2}{*}{\multicolumn{1}{c}{ Source of knowledge }} & \multicolumn{2}{c}{ Sensory } & \multicolumn{2}{c}{ Coded } & \multicolumn{2}{c}{ Theoretical } \\
\cline { 2 - 7 } & Mean & SD & Mean & SD & Mean & SD \\
\hline Buyers & 3.79 & 0.93 & 3.90 & 0.98 & 3.91 & 0.88 \\
Suppliers & 3.62 & 1.01 & 3.88 & 0.87 & 3.79 & 0.97 \\
Competitors & 3.22 & 1.05 & 3.28 & 1.04 & 3.43 & 0.99 \\
Consultants & 3.50 & 0.97 & 3.53 & 1.07 & 3.71 & 0.90 \\
Government offices & 2.93 & 0.92 & 3.25 & 1.04 & 3.25 & 1.16 \\
Industry associations & 3.22 & 1.08 & 3.50 & 0.95 & 3.42 & 0.97 \\
Religious affiliations & 3.38 & 1.04 & 3.79 & 0.80 & 3.20 & 0.94 \\
Research institutions/universities & 3.13 & 0.74 & 3.33 & 0.98 & 3.18 & 1.07 \\
Exhibitions & 3.41 & 0.93 & 2.69 & 0.98 & 3.69 & 1.08 \\
Magazines/newspapers & 3.35 & 1.00 & 3.64 & 1.09 & 3.66 & 1.10 \\
Television & 2.96 & 1.11 & 3.38 & 1.24 & 3.41 & 1.40 \\
Radio & 2.13 & 1.46 & 2.63 & 1.60 & 2.22 & 1.64 \\
Internet & 3.69 & 0.88 & 3.89 & 0.90 & 3.90 & 0.87 \\
\hline
\end{tabular}

Notes: Measured using a 5-point Likert scale ( $1=$ little sensory $/$ less coded $/$ less theoretical and $5=$ much sensory $/ \mathrm{more}$ coded/more theoretical) 


\section{Type of external knowledge}

\section{Sensory knowledge}

Knowledge obtained from the buyers $($ mean $=3.79)$ is perceived as the most sensory by the furniture firms, followed by knowledge from Internet (mean=3.66) (see Table 2). As indicated, sensory knowledge is dependent on its context and can only be obtained through imitation (Jorna 2006). For example, when buyers order particular outdoor tables/chairs made of mahogany wood, they provide the company with a detailed description of the model, including the preferred size, colors, and shape. They may also provide pictures. Based on this information, the furniture firm manufactures the product. However, these buyers only seldom provide information on how to process the raw material, in this case the mahogany wood. This finding may be explained by the nature of the knowledge provided by these sources. It is generally perceived that this knowledge provides only a few contextual references and clues for imitation.

Surprisingly, the external knowledge from the radio, government offices, and the television is regarded as the least sensory. Knowledge provided by the radio is transferred by sound, while the television sends sounds and images to its receivers (Crisell 1986). From the perspective of the furniture firms, the knowledge offered by these sources is the most accessible compared to that of other providers. The ubiquitous quality of these sources may explain this accessibility. However, in spite of the transparency of the knowledge provided by these sources (of which that of the radio is perceived as the least sensory knowledge and therefore the easiest to absorb), the current study shows that the furniture firms only rarely address these sources for obtaining knowledge in the product, process, and organizational domains.

\section{Coded knowledge}

The furniture firms indicated that the knowledge from the buyers (mean $=3.66)$ and the Internet (mean=4.05) are the most coded (see Table 2). The more coded the knowledge, the more accessible it is to be absorbed. The radio provides the least coded knowledge of all sources. The radio is considered as a blind medium (Crisell 1986:3), which means that people cannot see its messages; it merely consists of sound and silence. This characteristic makes knowledge from the radio more difficult to understand and transfer clearly to others. The information is more susceptible to ambiguity and may lead to paradoxical communication (Bateson et al. 1956).

\section{Theoretical knowledge}

The finding shows that the knowledge obtained from buyers (mean=3.91) is the most theoretical knowledge, followed by the Internet (mean=3.90) (see Table 2). The interviews with the owners told us that the production of the goods is generally based on the information from the buyers who ordered them (Gereffi 1998). Often, the contents of this information lack detail and are not explained properly, which makes the knowledge more theoretical. Likewise, the knowledge from the Internet often contains various knowledge domains, which also increases its complexity. Since the knowledge absorbed from these sources is considered to have a longer why-chain, it is more theoretical. 


\begin{tabular}{|c|c|c|c|c|c|c|c|}
\hline \multirow[b]{2}{*}{ No. } & \multirow[b]{2}{*}{$\begin{array}{l}\text { Type of } \\
\text { initiative }\end{array}$} & \multirow[b]{2}{*}{$\begin{array}{c}\text { Degree of } \\
\text { initiativeness }\end{array}$} & \multicolumn{2}{|c|}{ Initiatives $^{\mathbf{a}}$} & \multicolumn{2}{|c|}{ Innovations $^{a}$} & \multirow[b]{2}{*}{$\mathbf{t}$} \\
\hline & & & Mean & SD & Mean & SD & \\
\hline \multirow[t]{2}{*}{1} & Product/service & Really new & 2.87 & 1.64 & 3.04 & 1.51 & -1.38 \\
\hline & & Modification & 2.77 & 1.54 & 3.12 & 3.12 & $-3.07 * * *$ \\
\hline \multirow[t]{2}{*}{$2 \mathrm{P}$} & Process & Really new & 2.00 & 1.72 & 1.97 & 1.56 & 0.22 \\
\hline & & Modification & 1.93 & 1.70 & 2.17 & 2.17 & $-1.69 *$ \\
\hline \multirow[t]{2}{*}{$3 c$} & Organizational & Really new & 1.52 & 1.62 & 1.31 & 1.41 & $2.04 * *$ \\
\hline & & Modification & 1.41 & 1.57 & 1.80 & 1.80 & -0.78 \\
\hline
\end{tabular}

Note: ${ }^{\text {a }}$ Measured by a 5 -Likert scale $(1=$ seldom to $5=$ very often $)$

$$
{ }^{*} p<0.1,{ }^{* *} p<0.05,{ }^{* * *} p<0.01
$$

\section{Innovation Capability: Initiatives and Innovations}

The findings show that product/service initiatives/innovations are found to be the most dominant type of initiatives and innovation (see Table 3). Furthermore, the frequency of product/service initiatives in general is lower than that of product/service innovation produced. The opposite cases are found among process and organizational innovations. From in depth interviews, we find that in many cases, the furniture firms make product/service innovations on the spot in the field without going through any planning stages. Productions of new furniture that are often based on order from buyers are also of explanations of the findings.

The findings as discussed above are in line with the nature of furniture business as a manufacturing firm, whose main activity is producing product/service. In the context of SMEs in Indonesia, where most of them are limited by financial capacity, focus is put on innovations that have a direct impact on the revenue of the firms. Impact of process and organizational innovations are less visible in a short time than that of product/service innovations.

From the degree of innovativeness, the study shows that the furniture firms produce more outputs in terms of modification (i.e. incremental) than those that are really new (i.e. radical), see Table 3 . In the context of SMEs in Indonesia, these findings are expected and understandable. Nature and characteristics of SMEs, which main activities of those firms are not, derived internally but from outside (i.e. buyers and competitors) make them unable to yield radical outputs. Lack of resources (i.e. financial, technical, infrastructure and management) is one of the reasons that hinder and change a firm's orientation; put more focus on incremental activities.

\section{Effect of Knowledge Stickiness on a Firm's Innovation Capability}

To examine the effect of knowledge stickiness on a firm's innovativeness, a regression analysis is performed (see Table 4). Out of four dimensions of stickiness, only theoretical knowledge does not affect a firm's innovativeness significantly. As predicted, 
Table 4. Results of the Regression Analysis

\begin{tabular}{lcc}
\hline \multicolumn{1}{c}{ Variable } & $\boldsymbol{B}$ & $\mathbf{t}$ \\
\hline Knowledge inter- & & \\
connectedness & 0.45 & $5.01 * * *$ \\
Sensory knowledge & -1.98 & $-1.68 *$ \\
Coded knowledge & 0.39 & $3.18^{* * *}$ \\
Theoretical knowledge & 0.02 & 0.13 \\
$F(4,83)$ & $12.96 * * *$ \\
$R^{2}$ & 0.38 & \\
Adjusted $R^{2}$ & 0.36 & \\
\hline
\end{tabular}

Note: ${ }^{*} p<0.1,{ }^{* *} p<0.05,{ }^{* * *} p<0.01$

knowledge interconnectedness and coded knowledge have a positive significant impact on a firm's innovation capability $\left(\mathrm{H}_{4}\right.$ and $\mathrm{H}_{2}$ are supported), while sensory knowledge does it in a negative direction ( $\mathrm{H}_{1}$ is confirmed).

Although in general, however, the interconnectedness of the knowledge absorbed by the firms in our sample is low (see Table 2), it still has a significant impact on the innovation capability. As order-based manufacturer, the buyers associated with the furniture firms generally provide detailed information about the products ordered, for example by means of pictures, schemes, or formulae. The more coded this knowledge, the easier it is for the firms to utilize this information in the development of their innovation projects. In this respect the availability of coded knowledge is highly crucial, especially in view of the product demands of their buyers, which have to be met (Hendry 1998; Gereffi 1999; Van Geenhuizen and Indarti 2008).
In the furniture sector, most knowledge required is practical know-how (Polanyi 1960), for example about how to make a table, how to cut/connect wood effectively, and how to preserve it. The tasks and activities in this sector require the imitation of already existing approaches and methods, which are best transferred by means of sensory knowledge (Jorna 2006). The more sensory the knowledge, the more difficult it is to absorb, hence the innovation capability is lower.

As indicated by the regression analysis, the four dimensions of knowledge stickiness explain 36 percent of the total variance of a firm's innovation capability.

\section{Concluding Remarks}

In this study, author took furniture firms as an emerging economy as a point of reference, and we found that SMEs nowadays are in a more volatile situation due to an everchanging business environment. To cope with such a situation, the SMEs have no choice other than to innovate to sustain their existence in the face of tighter competition and to achieve operational excellence. Actual innovation conducted within the SMEs is relatively modest, and most of the SMEs put emphasis on incremental innovations rather than radical ones. The SMEs paid substantial attention to product innovation that promptly led to direct financial benefits and was less risky, while less attention was paid to process and organizational innovation.

The current study shows that the less sticky the external knowledge, the higher the innovation capability of a firm. Knowledge stickiness has a significant impact on a firm's innovativeness. The more interconnected, the less sensory, and the more coded the external knowledge as perceived by the firms, the 
higher the firms' innovativeness. The availability of coded knowledge, less sensory knowledge, and more interconnected knowledge is very crucial, especially in the context where the firms are commonly operating based on orders.

Another new insight provided by the study is that division of knowledge types into sensory, coded, and theoretical ones is not mutually exclusive. A piece of knowledge provided by a single source of knowledge may, at the same time, consist of three of the types of knowledge mentioned above. Even, for instance, knowledge that theoreti- cally is characterized as coded knowledge, may be considered by a firm as sensory for several reasons, such as experiences and existing knowledge within a firm. Hence, this study also provided empirical evidence about how a piece of knowledge is characterized by a recipient in a specific context.

Although the focus of this study was SMEs in the Indonesian setting, given the facts that most SMEs operate on similar premises (Wattanapruttipaisan 2003), the findings then may be generalized for other contexts, especially in emerging economies.

\section{References}

Abernathy, W. J., and K. Clark. 1985. Innovation: Mapping the winds of creative destruction, Research Policy 14: 3-22.

Arrow, K. J. 1969. The economic implications of learning by doing. The Review of Economic Studies, 29 (3): 155-173.

Avermaete, T., J. Viaene, E. J. Morgan, and N. Crawford. 2003. Determinants of innovation in small food firms. European Journal of Innovation Management 6 (1): 8-17.

Barney, J. 1991. Firm resources and sustained competitive advantage. Journal of Management, 17 (1): 99 120.

Bateson, G., D. D. Jackson, J. Haley, and J. H. Weakland. 1956. Toward a theory of schizophrenia. Behavioral Science 1: 251-264.

Boisot, M. H. 1995. Information Space: A Framework for Learning in Organizations, Institutions and Culture. London, UK: Routledge.

Brown, J. S., and P. Duguid. 2001. Knowledge and organization: A social-practice perspective. Organization Science 12 (2): 198-213.

Cijsouw, R. S., and R. J. Jorna. 2003. Measuring and mapping knowledge types: Problems of knowledge transfer in an IT company. In Gazendam, H. W. M., Jorna, R. J., and Cijsouw, R. S. (eds.), Dynamics and Change in Organizations: Studies in Organizational Semiotics. London: Kluwer Academic Publisher.

Cohen, W. M., and D. A. Levinthal. 1990. Absorptive capacity: A new perspective on learning and innovation. Administrative Science Quarterly 35:128-52.

Crisell, A. 1986. Understanding Radio. London: Routledge.

Culnan, M. J. 1985. The dimensions of perceived accessibility to information: Implications for the delivery of information systems and services. Journal of the American Society for Information Science 36 (5): 302-308. 
Damanpour, F. 1996. Organizational complexity and innovation: Developing and testing multiple contingency models. Management Science 42: 693-716.

Davenport, T. H., and L. Prusak. 1998. Working Knowledge: How Organizations Manage What They Know. Boston: Harvard Business School Press.

Fann, G. L., and L. R. Smeltzer. 1989. The use of information from and about competitors in small business. Entrepreneurship, Theory and Practice 13: 35-46.

Foss, N. J., C. Knudsen, and C. A. Montgomery. 1995. An exploration of common ground: Integrating evolutionary and strategic theories of the firm. In Montgomery, C. A. (ed.), Resource-based Theories and Evolutionary Theories of the Firm. Boston: Kluwer Academic Publisher.

Gereffi, G. 1999. International trade and industrial upgrading in the apparel commodity chain. Journal of International Economics 48: 37-70.

Grant, R. M. 1996. Toward a knowledge-based theory of the firm. Strategic Management Journal 17: 109122.

Helfat, C. E. 1997. Know-how and asset complementarity and dynamic capability accumulation: The case of R\&D. Strategic Management Journal 18 (5): 339-360.

Hendry, L. C. 1998. Applying world class manufacturing to make-to-order companies: Problems and solutions. International Journal of Operations and Production Management 18 (11): 1086-1100.

Hoffman, K., M. Parejo, J. Bessant, and L. Perren. 1998. Small firms, R\&D, technology and innovation in the UK: A literature review. Technovation 18 (1): 39-55.

Hollifield, C. A., and J. F. Donnermeyer. 2003. Creating demand: Influencing information technology diffusion in rural communities. Government Information Quarterly 20 (2): 135-150.

Indarti, N., and M. Langenberg. 2004. Factors affecting business success among SMEs: Empirical evidences from Indonesia. Proceedings of The Second Bi-annual European Summer University 2004, University of Twente, Enschede, The Netherlands.

Jansen, J., F. A. J. Van Den Bosch, and H. W. Volberda. 2006. Exploratory innovation, exploitative innovation, and performance: Effects of organizational antecedents and environmental moderators. ERIM Report Series Reference No. ERS-2006-038-STR.

Jasimuddin, S. M., J. H. Kleinn, and C. Connell. 2005. The paradox of using tacit and explicit knowledge: Strategies to face dilemmas. Management Decision 43 (1): 102-112.

Johannessen, J.-A., B. Olsen, and G. T. Lumpkin. 2001. Innovation as newness: What is new, how new, and new to whom? European Journal of Innovation Management 4 (1): 20-31.

Jorna, R. J. 2006. Knowledge as a basis for innovation: Management and creation. In Jorna, R. J. (ed.), Sustainable Innovation: The Organizational, Human and Knowledge Dimension. Sheffield, UK: Greenleaf Publishing.

Kim, D-J., and B. Kogut. 1996. Technological platforms and diversification. Organization Science 7 (3): 283 301.

Kogut, B., and U. Zander. 1992. Knowledge of the firm, combinative capabilities, and the replication of technology. Organizations Science 3 (3): 383-397.

Kristiansen, S., J. Kimeme, A. Mbwambo, and F. Wahid. 2005. Information flows and adaptation in Tanzanian cottage industries. Entrepreneurship and Regional Development 17: 365-388. 
Kuncoro, M. 2000 The economics of industrial agglomeration and clustering, 1976-1996: The case of Indonesia (Java). Unpublished PhD Thesis. Melbourne: The University of Melbourne.

Lam, A. 1997. Embedded firms, embedded knowledge: Problems of collaboration and knowledge transfer in global cooperative ventures. Organization Studies 18 (6): 973-997.

Lane, P. J., B. R. Koka, and S. Pathak. 2002. A thematic analysis and critical assessment of absorptive capacity research. Paper presented at The Annual meeting of the Academy of Management, Denver.

Melody, W. H. 1985. The information society: Implications for economic institutions and market theory. Journal of Economic Issues 19: 523-539.

Mowery, D. C., J. E. Oxley, and B. S. Silverman. 1996. Strategic alliances and interfirm knowledge transfer. Strategic Management Journal 17: 77-91.

Neely, A., R. Filippini, C. Forza, A. Vinelli, and J. Hii. 2001. CA framework for analysing business performance, firm innovation and related contextual factors: perceptions of managers and policy makers in two European regions. Integrated Manufacturing Systems 12 (2): 114-124.

Nelson, R., and S. Winter. 1982. An Evolutionary Theory of Economic Change. Cambridge, MA: Belknap Press.

Nonaka, I. 1994. A dynamic theory of organizational knowledge creation. Organization Science 5 (1): 14-37.

Nonaka, I., R. Toyama, and A. Nagata. 2000. A firm as a knowledge-creating entity: a new perspective on the theory of the firm. Industrial and Corporate Change 9 (1): 1-20.

Nooteboom, B. 1996. Trust, opportunism and governance: A process and control model. Organization Studies 17 (6): 985-1010.

Penrose, E. 1959. The Theory of the Growth of the Firm, New York, NY: Wiley.

Pfeffer, J., and G. R. Salancik. 1978. The External Control of Organizations: Resource Dependence Perspective. New York: Harper \& Row.

Philips, R., and R. E. Freeman, and A. C. Wicks. 2003. What stakeholder theory is not. Business Ethics Quarterly 13 (4): 479-502.

Polanyi, M. 1962. The Tacit Dimension. New York: Anchor Day.

Porter, M. E. 1994. The role of location in competition. Journal of the Economics of Business 1: 35-39.

Porter, M. E. 1985. Competitive Advantage: Creating and Sustaining Superior Performance. New York: Free Press.

Reich, R. B. 1991. The Work of Nations. New York: Alfred A. Knopf.

Roberts, J. 2000. From know-how to show-how? Questioning the role of information and communication technologies in knowledge transfer. Technology Analysis and Strategic Management 12 (4): 429-443.

Rothwell, R. 1991. External networking and innovation in small and medium-sized manufacturing firms in Europe. Technovation 2: 93-112.

Schmidt, T. 2005. Absorptive capacity: One size fits all? Firm-level analysis of absorptive capacity for different kinds of knowledge. ZEW Discussion Papers (No. 05-72).

Schumpeter. J. A. 1934. The Theory of Economic Development. Cambridge: Harvard University Press.

Simon, H. A. 1976. How complex are complex systems? Proceedings of the Biennial Meeting of the Philosophy of Science Association (Volume Two: Symposia and Invited Papers): 507-522.

Smeltzer, L. R., G. L. Fann, and V. N. Nikolaisen. 1988. Environmental scanning practices in small business. Journal of Small Business Management 26 (3): 55-62. 
Szulanski, G. 1996. Exploring internal stickiness: Impediments to the transfer of best practices within the firm. Strategic Management Journal 17: 27-44.

Szulanski, G. 2000. The process of knowledge transfer: A diachronic analysis of stickiness. Organizational Behavior and Human Decision Processes 82 (1): 9-27.

Ulrich, D., and J. B. Barney. 1984. Perspectives in organizations: Resource dependence, efficiency, and population. Academy of Management Review 9 (3): 471-481.

Van den Bosch, F., H. Volberda, and M. de Boer. 1999. Co-evolution of firm absorptive capacity and knowledge environment: organizational forms and combinative capabilities. Organization Science 10 (5): 551-568.

Van der Spek, R., and A. Spijkervet. 1997. Knowledge management: Dealing intelligently with knowledge. In Liebowitz, J., and L. Wilcox (eds.), Knowledge Management and Its Integrative Elements. New York: CRC Press.

Van Geenhuizen. M., and N. Indarti. 2008. What role for knowledge access in innovation by small manufacturers in Indonesia? In van Geenhuizen, M., D. M. Trzmielak, D. V. Gibson, and M. Urbaniak (2008), Value-Added Partnering and Innovation in a Changing World. United States of America: Purdue University Press.

Van Geenhuizen, M., and N. Indarti. 2005. Knowledge as a critical resource in innovation among small furniture companies in Indonesia. Gadjah Mada International Journal of Business 7 (3): 371-390.

Von Hippel, E. 1994. Sticky information and the locus of problem solving: implications for innovation. Management Science 40: 429-439.

Wattanapruttipaisan, T. 2003. Four proposal for improved financing of SME development in ASEAN. Asian Development Review 2 (2) (December).

Zahra, S. A., and G. George. 2002. Absorptive capacity: A review, reconceptualization, and extension. Academy of Management Review 27: 185-203. 